Proc. Indian Acad. Sci. (Earth Planet. Sci.), Vol. 100, No. 3. September 1991, pp. 293-306.

(C) Printed in India.

\title{
Stratigraphy of the Lesser Himalayan rocks in Kumaun
}

\author{
L S CHAMYAL \\ Department of Geology, The Maharaja Sayajirao University, Baroda 390002 , India \\ MS received 27 November 1990; revised 1 April 1991
}

\begin{abstract}
The geology of Kumaun Lesser Himalaya falls within three main tectonic units, viz. the Almora Nappe, Inner Krol Nappe and the Outer Krol Nappe, and the three units comprising the entire succession occur in five distinct zones or belts. The stratigraphy of the area has been revised on the basis of the occurrences of chloritic horizons (spilites) and also the existence of an unconformity at the base of Loharkhet/Bageshwar/Ganai/Bhimtal Formation. This paper describes briefly the lithological and structural characters of the rocks of the five belts and the observations are synthesized to present an integrated picture of the regional stratigraphic framework for the metasediments lying between the Main Central Thrust and the Main Boundary Thrust/Fault which define the tectonic boundaries of the Lesser Himalaya in Kumaun.
\end{abstract}

Keywords. Stratigraphy; spilites; Berinag Thrust; Kumaun Lesser Himalaya.

\section{Introduction}

The geological studies of the Lesser Himalayan rocks of Kumaun Himalaya have always posed a challenge to geologists. Ever since Heim and Gansser (1939) extended Auden's concept eastward into Kumaun the metasedimentaries to the north and south of the Almora crystallines have generated considerable controversy in respect of their depositional history and precise stratigraphy. According to Gansser (1964), (i) the sedimentary rocks between the Baijnath Thrust and the Main Central Thrust, comprise an uninverted Deoban-Jaunsar sequence and (ii) these rocks can be traced from the Simla area in northwest to the border of Nepal in the southeast for about $350 \mathrm{~km}$. The rocks of this belt comprise the Garhwal series of Auden (1937), Chamoli-Tejam zone of Heim and Gansser (1939) and the Calc zone of Pithoragarh of Valdiya (1962). Gansser (1964) did not agree with Misra and Valdiya (1961) and unequivocally stated that the metasedimentary sequence of Pithoragarh was uninverted. In subsequent papers, Valdiya $(1978,1979,1980,1981)$ too modified his ideas about the inversion of the calc zone rocks. Instead of inversion, he postulated existence of a thrust between the carbonate rocks and the overlying quartzites, designating this tectonic plane as Berinag Thrust. According to him the Berinag Quartzites are the northerly prolongation of the Nagthat Quartzites.

Gansser's (1964) views that the trap-quartzite sequence of the Bhowali-Bhimtal area and that of the Saryu valley in the north are one and the same, being continuous below the Almora Crystallines, are of considerable relevance. Obviously, he considered these metasedimentary rocks of Bhowali-Bhimtal to be of Nagthat age. In BhowaliBhimtal area also, Valdiya (1978) invoked a comparable thrust. Fuchs and Sinha (1978) followed more or less Valdiya's concept of the Berinag Thrust, though they 
referred to the so-called dislocation to comprise one of their Chail group of thrusts. According to Fuchs and Sinha (1978) the quartzites of Bhowali were Nagthat, over which to the west of Bhowali came Blaini, comprising "a few metres of greenish quartzitic sandstone containing pebbles and boulders". Pande (1974) while discussing the geology of Nainital area putforth a stratigraphy more or less identical to that of Fuchs and Sinha; he also considered the variegated slates above the quartzites to belong to Blaini Formation.

Some contemporary workers, on the other hand, have not shown any thrust at the base of the quartzites (Nisra and Bhattacharya 1972; Ahmad 1975; Bhattacharya 1981) though they have described the geology of the area in fair detail. Studies by Bhattacharya (1981) in the Loharkhet area throw much light on the stratigraphy of the Lesser Himalayan rocks but he has not recorded any tectonic break between his Berinag and Saling Formations.

An altogether new stratigraphic framework of the Inner as well as Outer Lesser Himalayan rocks of Kumaun, was suggested by Merh and his associates (Merh 1977; Shah and Merh 1978; Chamyal and Merh 1985; Chamyal et al 1989). According to these workers, no thrusts exist either beneath the Berinag Quartzites or their equivalents at Chaukhutia, Someshwar, Ganai or Loharkhet in the Inner Lesser Himalaya, or at Ramgarh-Nathuakhan (Chail, Ramgarh Thrust) in the Outer Lesser Himalaya.

\section{Lithotectonic divisions}

Three major lithotectonic divisions are postulated within the Lesser Kumaun Himalaya, each characterized by distinctive lithology and structures (figure 1). They occur from south to north as follows:

(i) The Outer Krol Nappe para-autochthon comprising pre-Tertiary mildly metamorphosed sediments bounded by the Main Boundary Fault in the South and by the South Almora Thrust in the north.

(ii) The Almora Nappe comprising metamorphics that are intimately associated with granitic rocks. This Nappe is represented by three klippen, (i) The Almora crystallines in the central part, (ii) Baijnath and Askot crystallines in the northeast. The Almora crystallines are delimited by South Almora Thrust and North Almora Thrust whereas the Baijnath and Askot crystallines are by Baijnath and Askot Thrusts respectively. (iii) The two Inner Krol Nappes delimited by the North Almora Thrust and Main Central Thrust in the south and north respectively, comprise once again very mildly metamorphosed sediments.

The para-autochthonous rocks of Krol Nappe in Kumaun Himalaya, comprise four distinct belts; three in the north and one to the south of the synformally folded Almora Thrust. The Krol Nappe rocks to the south of South Almora Thrust form an anticline (at Bhowali) and a syncline (at Nainital) before finally resting over the Main Boundary Fault. The Krol Nappe rocks between the North Almora Thrust and Baijnath Thrust form a complicated anticlinal structure, which has been referred to as 'false anticline' by Heim and Gansser (1939). The northern most Krol Nappe rocks exposed between the Baijnath Thrust and the Main Central Thrust form a major anticlinal structure (Gansser 1964: Chamyal and Merh 1985). 


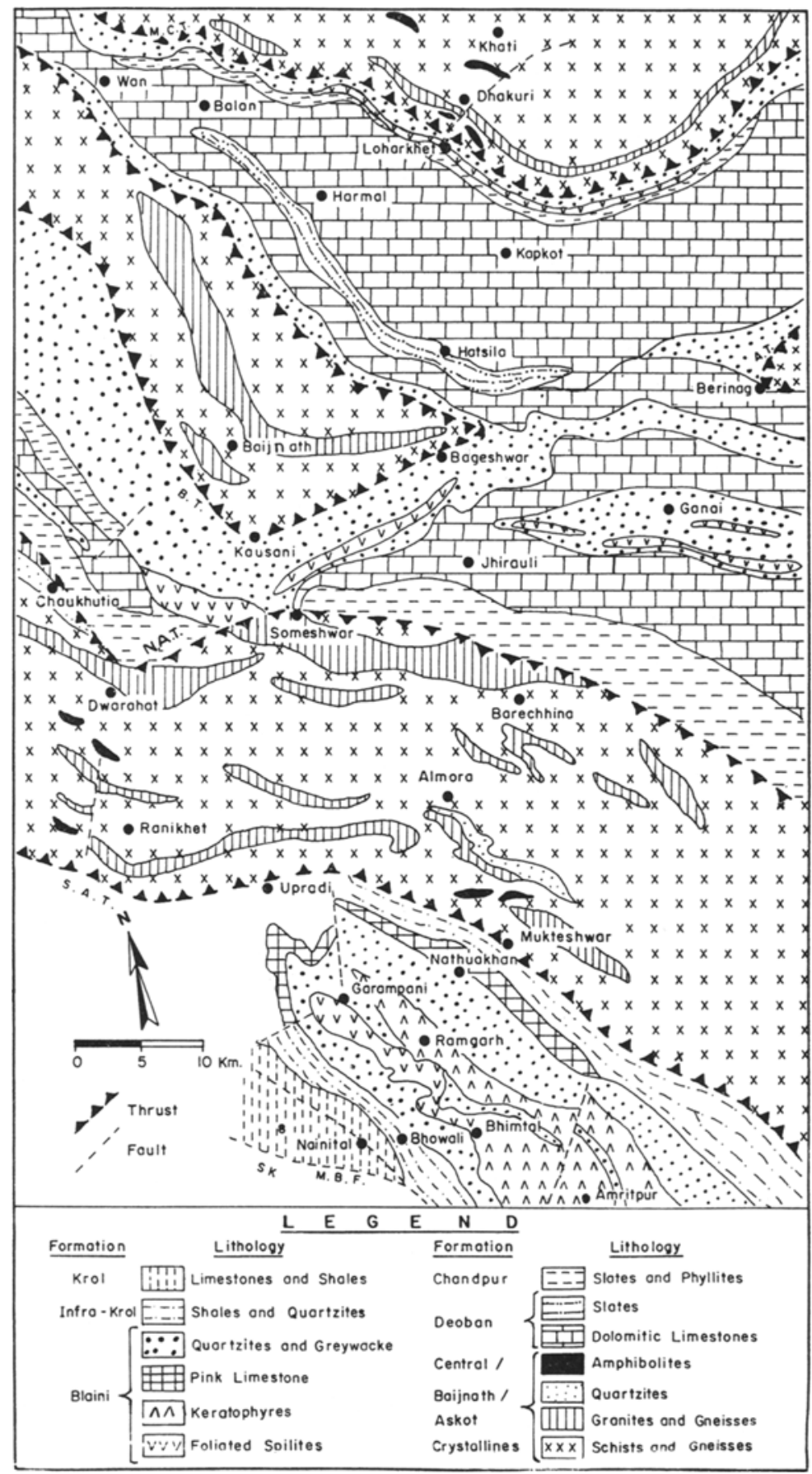

Figure 1. Geological map of Kumaun Himalaya (based on Merh 1977), M.C.T. (Main Central Thrust), B.T. (Baijnath Thrust), A.T. (Askot Thrust), N.A.T. (North Almora Thrust), S.A.T. (South Almora Thrust), M.B.F (Main Boundary Fault), SK (Siwaliks). 
The geology of Kumaun Lesser Himalaya broadly falls within two main tectonic units, viz. the Almora Nappe and the Krol Nappe, and the two units, comprising the entire succession occur in five distinct zones or belts as under:

1. Crystalline zones of Almora, Baijnath and Askot (Almora Nappe)

2. Kapkot-Loharkhet belt (Inner Krol Nappe) 3. Chaukhutia-Someshwar belt (Inner Krol Nappe) 4. Ganai-Berinag belt (Inner Krol Nappe) 5. Nainital-BhowaliRamgarh belt (Outer Krol Nappe).

In the following pages the author has described the lithological and structural characters of these zones or belts and then synthesized his observations to present an integrated picture of the regional tectonic and stratigraphic framework for the rocks of Kumaun Lesser Himalaya.

\subsection{Crystalline belts of Almora, Baijnath and Askot}

The rocks of this zone, which comprise the most dominant formation of the Lesser Kumaun Himalaya form part of the Central Crystallines, thrusted synformally southward (figures 1 and 2). In addition to the classic accounts of Heim and Gansser (1939) and Gansser (1964), these are investigated by several others (Powar 1972; Bhattacharya 1976; Valdiya 1980, 1981; Karanth 1985; Chamyal 1987; Chamyal and Vashi 1989). The rocks consist mainly of garnetiferous mica-schists, and within these occur layers of quartzite, lenses of graphitic schists and amphibolites and bands of gneissic rocks. Metamorphically they belong to the staurolite-almandine subfacies of the almandine-amphibolite facies.

The crystallines of Almora nappe have been found to preserve structural elements belonging to four tectonic episodes (Chamyal and Vashi 1989). The earliest two episodes are represented by tight to isoclinal-reclined folds $\left(F_{1}\right.$ and $\left.F_{2}\right)$ having similar geometry and orientation. The rocks were metamorphosed to almandine-amphibolite facies and the cleavages generated were sub-parallel to the bedding. The sub-parallel nature of the cleavages and the similar nature of those two foldings make it very difficult to distinguish them (Karanth 1985). The later deformations produced open folds $\left(\mathrm{F}_{3}\right.$ and $\left.\mathrm{F}_{4}\right)$ oriented right angles to each other.

\subsection{Kapkot-Loharkhet belt}

The tectonic succession of the Inner Krol Nappe occurring between Baijnath Thrust and the Main Central Thrust is presented in table 1. The study in the Kapkot-Loharkhet section has more or less substantiated the ideas of Merh (1977). The rocks of this belt though stratigraphically younger than the Central Crystallines, structurally lie below the latter. Inner Krol Nappe rocks to the south of the Main Central Thrust have been affected only by the last two fold events $F_{3}$ and $F_{4}$. Considering the regional structural perspective of the Krol Nappe rocks between Baijnath Thrust and the Main Central Thrust to the south and north respectively, the rocks of this belt comprise part of a large $F_{3}$ antiformal structure, the Loharkhet rocks lying on the northern flank of this $F_{3}$ antiform. The so-called Kapkot syncline of Gansser (1964), according to Merh (Personal communication) is a $F_{4}$ syncline superimposed over the $\mathrm{F}_{3}$ anticlinal crest.

The lowermost formation (Kapkot Formation), comprising a thick sequence of 
Stratigraphy of the Lesser Himalayan rocks

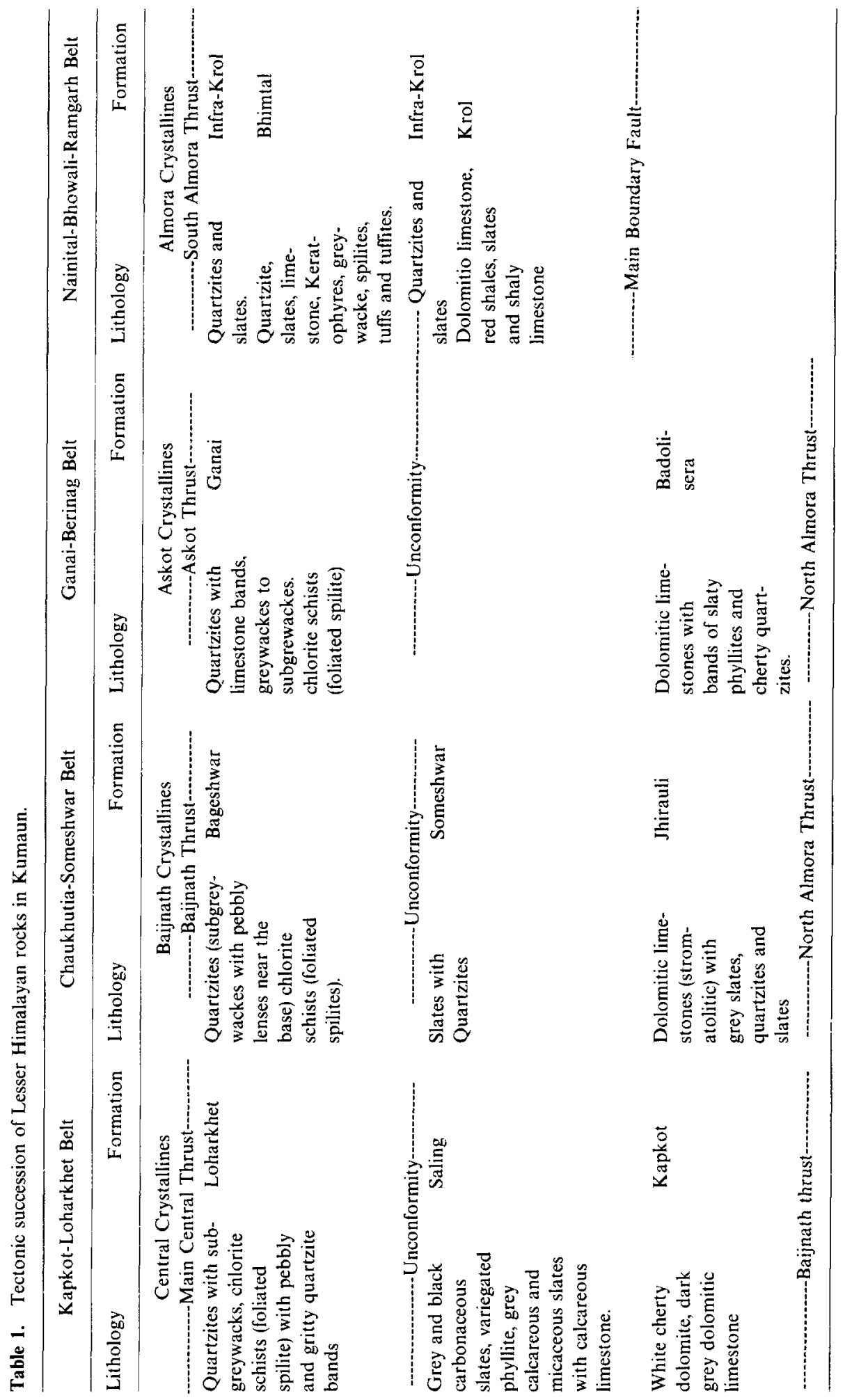


layered carbonate, dolomite and dolomitic limestone with interbedded thin slates, extends across the entire area from WNW to ESE. The presence of stromatolites and magnesite bands within the dolomitic limestone, is the characteristic feature. The rocks are very hard and compact, almost crystalline at many places. Numerous cream-coloured and purple slaty layers encountered in the middle portion of this formation have been found to be calcareous, pointing to the marly nature of original sediments.

The Kapkot Formation is conformably overlain by phyllitic rocks named Saling Formation by Misra and Bhattacharya (1972). The lower most horizon of this formation is seen to consist of a considerable thickness of slates with bands of calcareous limestone and dolomite within the phyllitic unit. This horizon is overlain by phyllites of various colours (grey, brown and greyish black) for which the term variegated has been used. In the black and grey varieties of this unit, pyrite is observed changing into yellow, brown, limonitic patches due to weathering. The uppermost horizon of this formation is made up of black carbonaceous slate.

The uppermost formation (Loharkhet Formation) which is arenaceous, is exposed ideally in the terrain to the north, northwest and southeast of Loharkhet. The contact between this formation and the underlying Saling Formation is controversial. While Valdiya (1978) and Fuchs and Sinha (1978) have shown a thrust between these two formations, other workers could not recognize this dislocation and they have more or less visualized a normal depositional contact. It has been observed that this contact is neither a thrust nor a gradational one and one tends to agree with Chamyal and Merh (1985), according to whom the contact between the overlying chlorite schists and the underlying rocks marks an unconformity. They take the overlying arenaceous sequence to be equivalent to the Blainis.

The basal portion of this formation comprising chlorite schist has been found to represent metamorphosed and foliated metabasics of spilitic affinity (Chamyal and Merh 1985; Chamyal et al 1989). It is worth mentioning that the chlorite schists contain lenses of chloritic pebbly and gritty quartzites and this phenomenon is typically indicative of penecontemporaneous volcanism. The basal spilitic portion (= chlorite schist) is seen merging upward rather gradationally into an arenaceous horizon which contains thin lenses and streaks of comparable chloritic material. The chlorite schists also contain occasional layers of chloritic quartzite, and quite often a distinct colour banding due to variation in the proportions of quartz and chlorite is observed. The overlying quartzites are creamy white, fine to medium grained and flaggy. The cross-section of the area (figure 2) and a generalized lithostratigraphic column (figure $3 \mathrm{~A}$ ) are shown.

The spilite which now occurs as chlorite schist at the basal portion of the Loharkhet Formation (figure 3A) forms a distinct horizon varying in thickness. Showing rather an abrupt junction with the underlying slates of the Saling Formation, the chlorite schists merge upward gradationally into the quartzites. The overlying quartzites contain numerous thin layers and lenses of chloritic material. On the basis of petrographic studies the chlorite schists (=metavolcanics) have been classified into three varieties. Chlorite schists; strongly foliated; fine grained basalts and foliated tuffs/tuffites.

Petrographically, the chlorite schists are seen to consist of chlorite, actinolite and quartz. Tremolite and plagioclase (An 10-15) are also present. The foliated fine-grained basalts under the microscope reveal a distinct relict flow texture, wherein stubby laths 


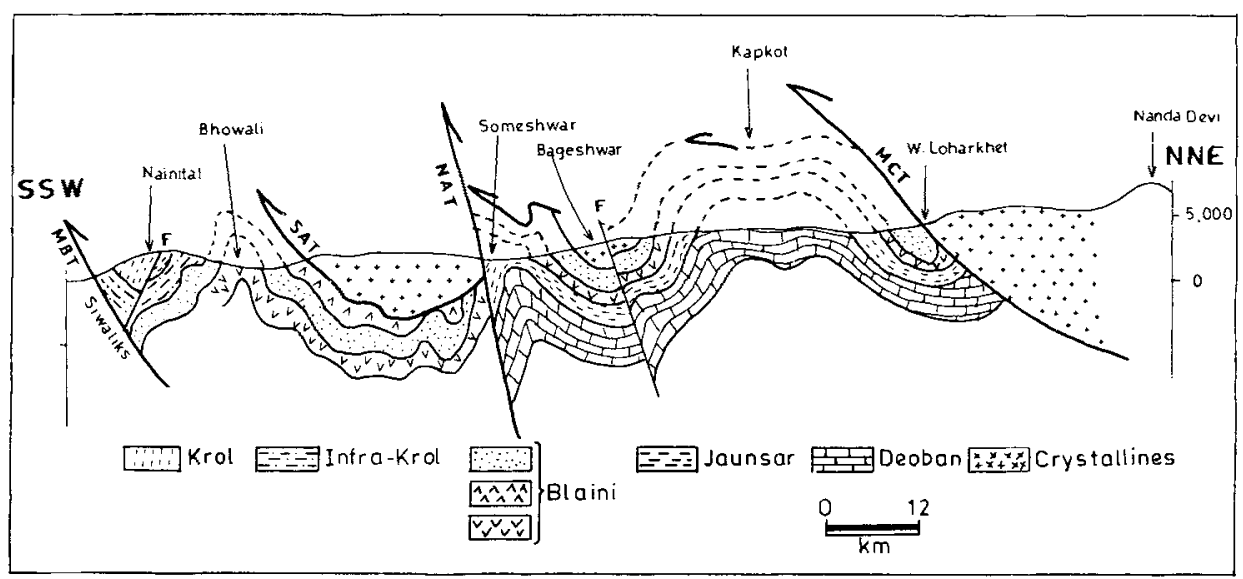

Figure 2. Generalized cross-section across Kumaun Himalaya (based on Merh 1977).

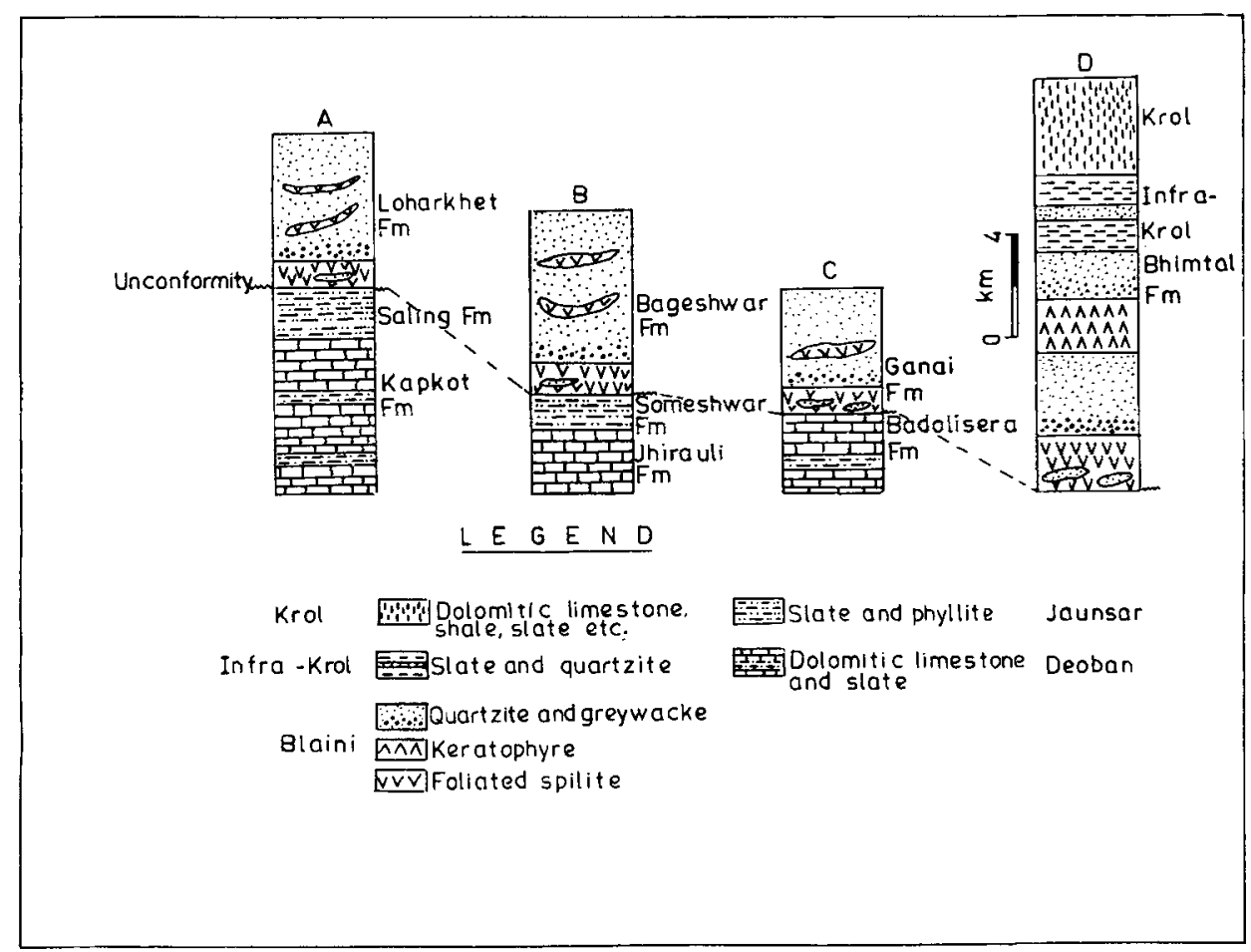

Figure 3. Generalized lithostratigraphy of Kumaun Lesser Himalaya (thickness of the litho-units measured approximately)(A) Kapkot-Loharkhet belt, (B) Chaukhutia-Someshwar belt, (C) Ganai-Berinag belt, (D) Nainital-Bhowali-Ramgarh belt.

of plagioclase are seen embedded in a chlorite uralite groundmass. The phenocrysts of plagioclase show parallelism, indicating the foliation to be an original layering. The feldspar grains which are quite fresh at places, are of oligoclase (An 10-15) composition. Streaks of cherty silica are commonly observed. Sphene and magnetite 
are the usual accessory minerals. The foliated tuffs/tuffites are fine-grained, dark greenish to greyish-green, strongly cleaved rocks. Under the microscope, it shows tiny grains of quartz and chert occurring individually, as clusters and as streaks within a very fine-grained foliated groundmass of chlorite, uralite and iron-oxide. This variety resembles the foliated spilitic tuff described by Shah and Merh (1976) from Bhowali-Bhimtal area.

\subsection{Chaukhutia-Someshwar belt}

The other belt of Inner Krol Nappe rocks occurring to the north of the Almora crystalline zone, exposed between the dislocation commonly designated as North Almora Thrust and the Baijnath Thrust form a complex structure (Merh 1977). According to Gansser (1964) the two thrusts represent two flanks of antiformally folded Almora Thrust, and as such the rocks beneath it should form an anticline. But it is not so, and the existing structure is rather intriguing. The north dipping limb is present, but the south dipping counterpart is missing and to the north of what is referred to as the North Almora Thrust, the rocks show a northerly dip. According to Merh (1977) this dislocation is not Almora Thrust, but is a later fault, which he called the North Almora Fault.

The Inner Krol Nappe rocks of this belt appear on crossing Almora Crystallines and the tectonic succession is as shown in table 1. Stratigraphically, the enitre succession could be correlated with the Jaunsars of Simla, the calcareous sequence being equivalent to the Deoban. A Late Precambrian to Early Cambrian age was assigned to the stromatolitic limestones by Misra and Valdiya (1961). The overlying quartzites have been generally taken as equivalent to Nagthat. Merh (1977), however, considers them to be much younger, possibly equivalent to Blaini. These rocks show effects of two-fold episodes $F_{3}$ and $F_{4}$. The effects of $F_{3}$ are quite pronounced.

The limestones occurring at Jhirauli, Dwarahat and Chaukhutia are stromatolitic and do not show any inversion. The slates above the limestones show development of axial plane cleavage. Over the slates, comes a horizon of dark green chlorite schists which have been found to be metamorphosed and cleaved mafic rocks and are overlained by pebbly quartzites (Merh 1977). The rocks of this belt possibly continue southward beneath the folded Almora Thrust, and appear again in the area south of South Almora Thrust (figure 2).

The chlorite schists to the south of and beneath the Baijnath Thrust rest over the stromatolitic limestones with an intervening slaty horizon; these chloritic rocks have been found to represent metamorphosed volcanics (figure 3B). According to Chamyal et al (1989) the chlorite schists of Someshwar were originally lava flows or sills which under conditions of extensive shearing during folding, have been metamorphosed into chlorite schists. Although they could not identify them as spilites, a perusal of the account of microscopic characters and chemical composition given by them clearly points to a spilitic affinity. The traverses in this area show that the chlorite schists, which abound in frequent cherty siliceous layers, show an almost identical gradational relationship with the overlying Quartzites. Pande (1977) categorically called the chlorite schists of Chaukhutia (which are the western extension of the Someshwar band) as foliated spilites. According to him the strongly foliated metabasics at Chaukhutia rest unconformably on the limestone. He classified the chlorite schists into three spilitic varieties i.e. foliated diabase; foliated basalt and foliated tuff. The petrographic and chemical characters clearly reveal their spilitic nature. 


\subsection{Ganai-Berinag belt}

Studies by Shah et al (1985) of this belt, have revealed a stratigraphic and tectonic framework which is at a variance from the earlier ones. Shah et al (1985) did agree with the actual sequence given by Valdiya (1962) or Gansser (1964), however they differed with their stratigraphic and structural interpretation. The structural sequence worked out is presented in table 1.

Valdiya (1979) has put a thrust beneath the chlorite schists, and has considered his Berinag Formation (= Ganai Formation) to be equivalent to Nagthats. At Ganai it is observed that the Berinag Quartzitic horizon becomes bouldary near its base, and finally merges into underlying chlorite schists (spilites), the transition being characterized by the presence of sporadic lenses of quartzites within in chlorite schists (figure 3C). The quartzites contain lensis of slightly recrystallized siliceous limestone. Thin sections of quartzites reveal their immature nature, the basal portions, quite often bouldary and pebbly, consist of a recrystallized impure rock quite identical to greywacke to subgreywacke. The field occurrence and petrography of the chlorite schists of this part not only point to their volcanic parentage, but thin sections of quite a few samples show that they represent spilitic rocks. Where unfoliated, they show distinct sub-ophitic texture, with laths of fresh and partly altered sodic plagioclase (An 10) randomly embedded in a chloritic-uralitic groundmass. In some thin sections, original ophitic and sub-ophitic texture and uralitization and chloritization of an original pyroxene is clearly observed. Some of the spilite samples reveal glassy texture and some are distinctly tuffaceous. Thus, the observations in this belt have provided support to the findings made at Loharkhet, Someshwar and Chaukhutia.

\subsection{Nainital-Bhowali-Ramgarh belt}

This sedimentary belt lying between the South Almora Thrust in the north and the Main Boundary Fault in the south has received maximum attention of geologists. According to Merh (1977) and Shah and Merh (1978), the rocks form an anticlinal structure at Bhowali and a syncline at Nainital. It is interesting to note that these two prominent structures belong to two distinct fold episodes, the one at Nainital being younger.

Heim and Gansser (1939) put their South Almora Thrust just above the pebbly and bouldary quartzites NE of Bhowali, and they equated the rocks lying above the thrust with the crystalline rocks of Almora Nappe. On the other hand Powar et al (1968) visualized a small synformal klippe-like mass of Almora Crystallines. However, Merh (1977) opined that the so-called metamorphic quartz porphyries do not belong to the Almora Nappe crystallines, but constitute an integral part of the Krol Nappe succession. There is no thrust at Ramgarh and the South Almora Thrust occurs further north and extends along Upradi-Mukteshwar. The rocks to the north and northeast of Nainital-Bhowali-Ramgarh area show the tectonic succession as presented in table 1 and a generalized lithostratigraphy (figure 3D).

The so-called 'metamorphic quartz porphyries' of Heim and Gansser (1939), or the migmatites of Pande (1956), have been found to be sheared quartz keratophyres and soda-granites. Mapping of these rocks by Desai et al (1976) show their extension up to the north of Ranibagh where they merge with soda-granites of Amritpur and with the spilitic traps on either side. Raina and Dungarakoti (1975) also observed this fact 
and thus found it difficult to put the South Almora Thrust below the 'porphyries'. In fact, the keratophyric rocks of Ramgarh extend southeastward as an antiformal structure and almost abut against the Main Boundary Fault.

The entire sequence between Bhowali and the South Almora Thrust is nowhere folded or inverted. The southwestern limb of the Bhowali-Bhimtal anticline $\left(F_{3}\right)$ comprises an almost unbroken sedimentary sequence and forms a $F_{4}$ syncline at Nainital which is faulted almost along its hinge (Merh 1977). The limestone band that rests on the bouldary quartzites extends'right from the Bhowali-Nainital road, crosses the river Kosi NW of Garampani (figure 1) and then swings eastward. The foliated traps that underlie the pebbly quartzites occupy the $F_{3}$ anticlinal core right from Garampani in the north to Amritpur-Ranibagh in the south, abut at places against the Main Boundary Fault. These traps are of spilitic nature and appear to be contemporaneous lava flows and tuff beds (Merh 1977). They contain numerous folded quartzite layers within them. To the southeast of Nainital, around Amritpur, the spilitic flows are associated with keratophyric rocks, and the soda-granite of the area (Amritpur granite) is an end product of a spilite-keratophyre kindred (Desai et al 1976).

The detailed study on these rocks reveals that the pebbly quartzites of Bhowali and Garampani, that rest over the foliated traps, may not be equivalent to Nagthat. A typical bouldary and greywacke nature, association of grey slates and a limestone band, all point to their being equivalent to the Blainis (Merh 1977; Shah and Merh 1978). The findings of Merh (1977) and Shah and Merh (1978) are of considerable structural and stratigraphical significance. The evidences point to the location of the South Almora Thrust along Upradi-Mukteshwar, and occurrence of Ramgarh Thrust has to be ruled out. The slate quartzite sequence just below the South Almora Thrust according to Merh (1977) could be Infra-Krol.

The metavolcanics (spilites) of this belt has received maximum attention in the past. Divakar Rao et al (1974) and Vardarajan (1974) has suggested spilitic nature for the Bhowali-Bhimtal basic volcanics. Shah and Merh (1976) and Desai et al (1976) have classified these spilitic rocks into several varieties and have worked out an ascending sequence of diabase-tuff-tuffite, occupying the core of the Bhowali-Bhimtal anticline. There is no doubt as regards their original parentage that they are spilitic. Megascopically, these rocks in this belt show much variation in grain size. Petrographically, these rocks are divisible into three types (Shah and Merh 1976); i.e. spilitic diabase, spilitic basalt and tuffs and tuffites. The layers of tuff and tuffites are seen associated with the above two varieties. The various deformational episodes and metamorphism have been responsible to modify the original nature of the spilites. But, still quite a few samples show the primary state which has been very useful in recognizing them as spilites.

Chamyal et al (1989) analysed ten representative samples (2 from Loharkhet, 2 from Ganai-Berinag, 2 from Chaukhutia, 2 from Someshwar and 2 from BhowaliBhimtal areas) of chlorite schists ( = metabasic) for major and trace element chemistry. Chemical studies are more revealing particularly the immobile elements to furnish strong evidences in support of the spilitic affinity, providing insight into their original composition. The chemistry of the chlorite schists (= metabasics) of Inner as well as Outer Krol Nappe reveal spilitic and alkali basaltic nature and are correlatable with each other. 


\section{Discussion}

The present investigations on the rocks of Lesser Kumaun Himalaya, are of considerable structural and stratigraphic significance and have fully substantiated the postulations made by Merh (1977). It is now possible to assign a more convincing stratigraphic positions to the various formations of the Krol Group rocks of Kumaun Lesser Himalaya. The revised stratigraphy is primarily based on a detailed mapping and thorough appraisal of the field characters, lithological aspects and relationships with the respective underlying and overlying formations. The most important criterion however, has been the recognition of the spilitic nature of the chlorite schists. Also, the fact that no thrust exist between the arenaceous and the argillaceous/calcareous zones, has been a vital evidence.

The oldest rocks exposed in the Inner Lesser Kumaun Himalaya are the dolomitic limestones (Kapkot/Badolisera/Jhirauli/Deoban). These are overlain by the slates (Saling/Someshwar/Chandpur Formation). These formations are correlatable with the Deoban and Jaunsar of Garhwal Himalaya (Gansser 1964; Ahmad 1975; Valdiya 1979; Bhattacharya 1961; Chamyal and Merh 1985; Shah et al 1985). However, the arenaceous sequence that comes above the slates and characterized by a basal horizon of spilitic metavolcanics has been assigned varying stratigraphic ages by different workers in various belts of Kumaun Lesser Himalaya. Heim and Gansser (1939), though not sure of the stratigraphic position of these rocks assigned with some uncertainity a much younger age to the calc zone, "being probably equivalent to the Krol series'. According to them, "if it (the limestone series) is Krol the large overlying quartzites must be Tals". Gansser (1964) correlated these calcareous rocks with the Deoban-Jaunsar sequence of Garhwal Himalaya. He was the first to suggest that the trap-quartzite sequence of Outer Lesser Kumaun Himalaya and that of Inner Lesser Kumaun Himalaya are correlatable. He correlated the arenaceous rocks that rest over the metabasics with Nagthats.

Merh (1977) envisaged an alternative stratigraphic model for the rocks of Chaukhutia-Someshwar and Nainital-Nathuakhan belt of Krol Nappe. He correlated the rock sequence of Chaukhutia-Someshwar belt of Inner Lesser Himalaya with the one encountered in the Nainital-Nathuakhan belt in the Outer Lesser Kumaun Himalaya. Merh (1977) further envisaged the quartzite-volcanic sequence of both Inner and Outer Krol Nappes to comprise the lowermost formation of the Krol Group, with a probable age of Lower Carboniferous to Permocarboniferous.

As regaras the stratigraphic ages of the various other formations of the Lesser Kumaun Himalaya Deoban has generally been taken to be of Precambrian to Ordovician age by most workers (Auden 1937; Gansser 1964; Merh 1977; Valdiya 1979; Bhattacharya 1981). The Calc zones of Kumaun (Kapkot/Badolisera/Jhirauli/Deoban) comprising stromatolitic limestones with associated slaty layers, could be considered as broadly of Precambrian to Ordovician age and the overlying argillaceous formation (slate and phyllite) of Silurian to Devonian age.

The presence of any tectonic break between the argillaceous/calcareous and arenaceous rocks is ruled out and an unconformity is invoked in the Outer as well as Inner Lesser Kumaun Himalaya (Merh 1977; Shah and Merh 1978; Shah et al 1985). Thus the rocks above the unconformity viz. spilites with pebbly and gritty quartzites, subgrey-wacke and siliceous limestone bands, are equated with the Blaini 


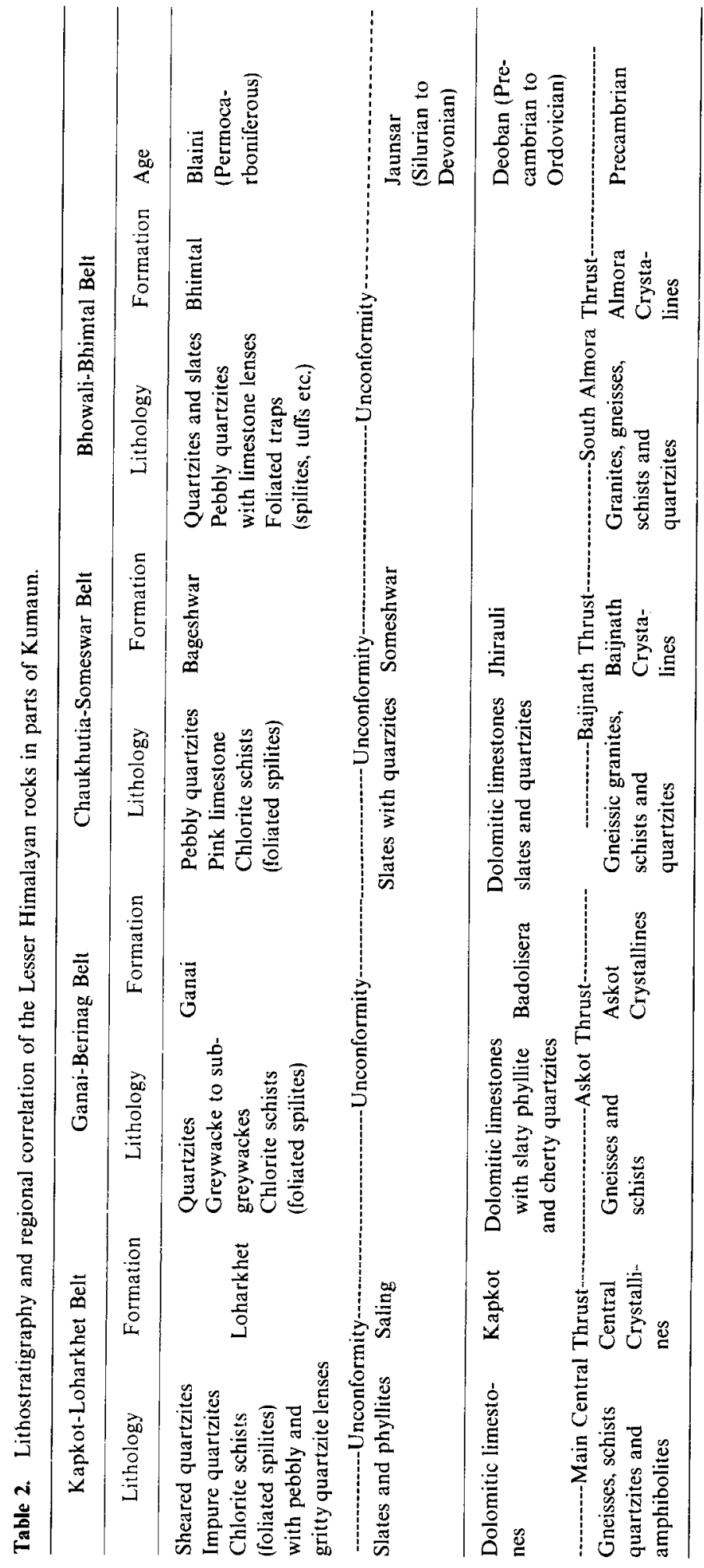


Formation of Simla (Niyogi and Bhattacharya 1971) and assigned an Permocarboniferous age. A detailed stratigraphic framework of the rocks of Kumaun Lesser Himalaya is presented (table 2).

\section{Acknowledgements}

The author is indebted to Prof. S S Merh for valuable guidance and constant encouragement. He also wishes to acknowledge the valuable comments and suggestions offered by the referee, which contributed significantly to this work.

\section{References}

Ahmad A 1975 Geology and structure of the area north of Bageshwar, District Almora, Uttar Pradesh; Himalayan Geol. 5 144-207

Auden J B 1937 The Structure of the Himalayas in Garhwal; Rec. Geol. Surv. India 71 407-433

Bhattacharya A R 1976 Tectonics and structural evolution of the Baijnath Crystallines, Kumaun Himalaya; Chayanica Geol. 2 181-195

Bhattacharya A R 1981 Stratigraphy and correlation of the Inner Kumaun Lesser Himalaya; implications of a mathematical study; Cont. Geos. Res. Him. (ed.) A K Sinha 137-150

Chamyal L S 1987 Some petrographic studies on the Crystalline rocks of Dhakuri area in Kumaun Himalaya; J. Indian Academy Geosci., Hyderabad 30 1-15

Chamyal L S and Merh S S 1985 Metabasics of Loharkhet in Kumaun and their stratigraphic significance; Current trends in geology (eds) A K Bhattacharya, M S Srinivasan, R K Lal and V K Gairola (New Delhi; Today and Tommorrows Printers and Publisher) Vol. 7, pp. 353-378

Chamyal L S and Vashi N M 1989 Tectonic framework and structural characteristics of the crystalline rocks of Kumaun Himalaya; Current trends in geology (eds) P S Saklani (New Delhi: Today and Tomorrows Printers and Publisher) Vol. 11, pp. 91-106

Chamyal L S, Vashi N M and Shah O K 1989 Metavolcanics of Lesser Kumaun Himalaya; Current trends in geology (ed) P S Saklani (New Delhi: Today and Tomorrows Printers and Publisher) Vol. 12, pp. $195-210$

Desai S J, Patel S G and Merh S S 1976 Spilite-Keratophyre-sodagranite association of Ranibagh-Amritpur in Nainital District of Kumaun Himalaya: Himalayan Geol. 6 449-466

Divakar Rao V, Satyanarayana K, Naqvi S M, Hussain M and Dileep K 1974 Geochemistry and petrogenesis of basic rocks from Bhowali, UP; Geophys. Res. Bull. 12 64-73

Fuchs G R and Sinha A K 1978 The tectonics of the Garhwal Kumaun Lesser Himalaya; Sond. Jahrb. Geol. 121 219-241

Gansser A 1964 Geology of the Himalayas (London: Interscience) p. 289

Heim A and Gansser A 1939 Central Himalaya: Geological observations of Swiss expedition 1936; Reprinted Delhi Hind. Publ. Co. 246

Karanth R V 1985 New Petrographic data on the metapelites of Almora Crystallines in Kumaun Himalaya; J. Geol. Soc. India $26435-452$

Merh S S 1977 Structural studies in the parts of Kumaun Himalaya; Himalayan Geol. $726-42$

Misra R C and Bhattacharya A R 1972 Geology of the area around Kapkot, District Almora, Uttar Pradesh; Himalayan Geol. 2 252-270

Misra R C and Valdiya K S 1961 The Calc-zone of Pithoragarh with special reference to the occurrence of stromatolites and the origin of magnesite; J. Geol. Soc. India 2 78-90

Niyogi D and Bhattacharya S C 1971 A note on the Blaini Boulder Beds of the Lower Himalaya; Himalayan Geol. $1111-122$

Pande I C 1956 Migmatites of Ramgarh (Dist. Nainital) UP; J. Sci. Res. B.H.U. 7 88-105

Pande I C 1974 Tectonic interpretation of the geology of Nainital area; Himalayan Geol. 4 532-546

Pande R N 1977 A reinterpretation of the geology of Ganai-Chaukhutia area in Kumaun Himalaya; Ph.D. thesis M.S.U. Baroda 
Powar K B 1972 Petrology and structure of the Central Crystalline zone, north-eastern Kumaun; Himalayan Geol. 2 34- 46

Powar K B, Gairola V K and Dixit P C 1968 Relationship between volcanism, plutonism, regional metamorphism and tectonism in Himalayan orogeny as revealed by rocks of part of Kumaun Himalayas; Pub. Cent. Adv. Siudy in Geol. Chandigarh 6 1-7

Raina B N and Dungarakoti B D 1975 Geology of the area between Nainital and Champawat, Kumaun Himalaya. Uttar Pradesh; Himalayan Geol. 5 1-28

Shah O K and Merh S S 1976 Spilites of the Bhimtal-Bhowali area, District Nainital, UP: Himalayan Geol. 6 423-448

Shah O K and Merh S S 1978 Structural geology and stratigraphy of Bhimtal-Bhowali area in Kumaun Himalaya-A reinterpretation; J. Geol. Soc. India 19 91-105

Shah O K, Patel S G and Chamyal L S 1985 Stratigraphic significance of the rocks of Ganai area in Kumaun Himalaya; Proc. Fifth Indian Geol. Cong. (ed) B Bhaskar Rao (Bombay) pp. 1-10

Valdiya K S 1962 An Outline of the stratigraphy and structure of the southern part of Pithoragarh dist. Uttar Pradesh: J. Geol. Soc. India $327-48$

Valdiya K S 1978 Fxtension and analogous of the Chail Nappe in the Kumaun Himalaya: Indian $J$, Earth Sci. $51-19$

Valdiya K S 1979 An outline of the structural set up of the Kumaun Himalaya; J. Geol. Soc. India 20 147-157

Valdiya K S 1980 The two intracrustal boundary thrusts of the Himalaya; Tectonophysics 66 323-348

Valdiya K S 1981 Tectonics of the central sector of the Himalaya; Him. Geody. Evol. Geody. Sr. 3 87-110 Vardarajan S 1974 Prehnite-pumpellyitic-metagreywacke facies of metamorphism of the metabasites of Bhimtal-Bhowali area. Nainital district, Kumaun Himalaya, India; Himalayan Geol. 4 581-599 